\title{
A final frenzy for landmark cases?
}

\section{Washington}

ANY new year resolution to say no more about misconduct and Robert Gallo, Thereza Imanishi-Kari or David Baltimore will almost certainly be broken. This may, however, be the last year in which that is the case. After years of heated rhetoric and conflicting claims, several landmark cases in the evolution of scientific misconduct policy are nearing their end.

\section{Imanishi-Kari}

The 1986 Cell paper has been retracted, co-author David Baltimore has resigned as president of the Rockefeller University, a draft report from National Institutes of Health (NIH) investigators found evidence of misconduct, and yet the case of Thereza Imanishi-Kari and her immunology research could still have a few more scenes to play out.

The US attorney in Baltimore, Maryland, may seek an indictment on criminal charges as early as late January. But now that Suzanne Hadley, the principal investigator in the case, has been forced to resign from NIH's Office of Scientific Integrity (OSI), the misconduct office is backpedalling as fast as it can from her damning draft report, which was leaked last year. (In fact, OSI no longer even calls it a draft report. Officials now refer to it as the "cross-examination report" and say that the final document in the case will probably bear little resemblance to what has been seen so far.)

But until Imanishi-Kari and her lawyer agree to cooperate, OSI is deadlocked. Imanishi-Kari has refused to comment on

\section{Growing up in public}

\section{Washington}

If the modern era of scientific misconduct was born two and a half years ago when the National Institutes of Health (NIH) created the Office of Scientific Integrity (OSI), 1991 was its awkward adolescence. The year opened with a nation watching the investigations of AIDS pioneer Robert Gallo and immunologist Thereza Imanishi-Kari (and by extension, her co-author David Baltimore), as well as open warfare over the operation of the OSI. And, unfortunately, it closed just the same way.

In the intervening 12 months, Suzanne Hadley resigned as the deputy director of OSI, and Representative John Dingell (Democrat, Michigan) strongly criticized NIH for its bungled handling of the whole issue. Other than that, not much changed. Investigation of scientific misconduct was a mess last year, and it is a mess today.

However, 1992 may be the year in which misconduct grows up. For one thing, the investigations of Imanishi-Kari and Gallo - OSI's flagship cases - seem to be winding down, though slowly (see story this page). And although those cases have been long, ugly affairs, they have opened up the misconduct system as never before.

Through congressional hearings, a phenomenal amount of news coverage, and the attention of virtually every element of the scientific community, the pitfalls of misconduct investigating are now a matter of public record. Leaks are one problem. So are inconsistent procedures (for instance, prominent researchers got special review committees, although others did not). In both the Imanishi-Kari and the Gallo case, NIH investigators were often reduced to a role of following up allegations in the press, which made nearly everyone but Dingell uncomfortable. And an important debate over 'due process' in OSI investigations has, intentionally or not, essentially halted several cases.

Even OSI admits that some of its most prominent investigations were badly handled. But it has also learned some tricks on the job: to avoid leaks, sensitive drafts reports now go only to principal parties, and OSI is increasingly employing forensic and statistical analysis to add some quantitative rigour to what has often been a disquietingly subjective process. Investigations now focus on whether misconduct occurred, and no longer stumble on the question of a researcher's intent. As OSI discovered, claims of "unintentional" misconduct have flummoxed many university investigations, even when they turned out to be a red herrings that obscured clear abrogation of scientific responsibilities.

Other changes at OSI are coming from outside. After losing a lawsuit that challenged the way it developed its procedures, OSI published a set of proposed new rules last year. Public comments were generally scathing, mostly focused on the proposed definition of misconduct, which included, together with the usual "fabrication, falsification and plagiarism", the category of "other practices that seriously deviate from those that are commonly accepted from the scientific community". An NIH advisory committee has recommended that the catchall phrase be changed to "other fraudulent activities in proposing, conducting, reporting or reviewing research", a definition that OSI says it can live with.

The committee also proposed - and NIH agreed - that OSI's staff be increased from 19 to 28 , including, for the first time, three lawyers (OSI investigators have traditionally been scientists). And the committee recommended open hearings, in which accused and accuser can face each other. OSI director Jules Hallum opposes that move, arguing that face-to-face confrontations "would destroy the willingness of whistle-blowers to come forward."

Even as it reconsiders its role, however, OSI languishes in a sort of bureaucratic limbo. Both Congress and some Administration officials are contemplating taking OSI away from NIH and placing it instead under the wing of the Department of Health and Human Services, NIH's parent agency. When Dingell held a hearing last summer accusing Bernadine Healy, the NIH director, of a conflict of interest in an OSI investigation of a case at the Cleveland Clinic. Healy's former institution, it only reinforced the concern that $\mathrm{OSI}$ - located on a campus full of scientists - is vulnerable to pressures from the scientific community. Dingell thinks OSI might be more independent if it operated like any other government investigative office - firmly entrenched in the bureaucracy. If the administration does not propose the move itself, congressional legislation to that effect may appear this year.

But the worst may be behind the misconduct controversy, if not OSI itself. Perhaps the most encouraging sign is the improving quality of university investigations. Whereas academic panels in the past often erred on the side of finding no misconduct, Hallum says that recent university investigations such as two last year at the California Institute of Technology, have been more thorough and fair. "If they keep it up, they may put us out of business," he says. Nevertheless, until conspicuous mishandlings such as Imanishi-Kari's inquiry at the Massachusetts of Technology and that of whistle-blower Erdem Cantekin at the University of Pittsburgh (see story, next page) become a thing of the past, OSI wants to keep tight reigns on the universities. The proposed new procedures would allow OSI to intercede earlier in an academic investigation if things seem to be going awry, and Hallum is hoping to have the rules clarified to give OSI explicit authorization to investigate the universities themselves, to explore the possibilities of cover-ups.
Christopher Anderson 
the draft report (beyond an attack on the overall process) until she is allowed to see the original laboratory notebooks on which OSI and other federal investigators carried out the forensic analysis that led them

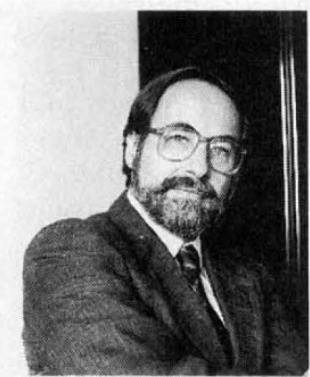

David Baltimore data had been fabricated. Many of those notebooks, however, are in the hands of the US attorney, who has declined OSI's repeated request to turn them over to Imanishi-Kari. If to conclude that a grand jury reaches an indictment, a legal process known as 'discovery' will allow ImanishiKari and her lawyer to examine the data. Until then, OSI considers its hands tied.

The congressional Investigations and Oversight Committee of Representative John Dingell (Democrat, Michigan), which has held four hearings on the case since 1988, may hold its last in the spring - a 'lessons learned' hearing to review the way in which NIH and the relevant universities handled the allegations.

\section{Gallo}

AIDS pioneer Robert Gallo had a stormy year in 1991, and 1992 may be almost as bad, but at least one cloud should soon clear. Sources close to the investigation say that OSI is nearing completion of a report that should essentially clear Gallo of scientific misconduct in identifying and claiming the AIDS virus on the basis of a sample that later turned out to be an isolate from French scientists. In its place a new dispute is likely to arise over the 1987 patent on the AIDS test, which, by agreement, is shared by the United States and France. Central to the controversy is the question of whether Gallo - and by extension, US government officials - knew at the time of the patent application that the virus had actually been first isolated by the French.

French government officials and their lawyers are lobbying their US counterparts to reopen

the patent agreements, on the grounds that they were clearly based on assumptions that have turned out to be untrue. The 1987 agreement allowed for that prospect, but not for the possibil-

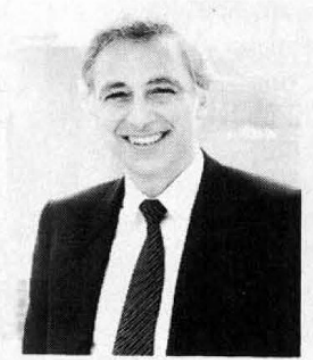

Robert Gallo

ity that the statements were known to false at the time they were made. Dingell's staff, who have closely followed the case, are pursuing allegations that Gallo knew about a 1984 study conducted by Donald Francis of the US Centers for Disease Control that showed that the US and French blood tests performed at about the same level, something that would have indicated that the French had indeed isolated the real AIDS virus.

There is little doubt that a study was performed. What Dingell must prove is that Gallo was aware of the study's conclusion at the time, and that the study did show convincingly that the blood tests performed similarily. Joseph Onek, Gallo's lawyer, says that he has not seen such a study and knows of "absolutely no evidence to support the charges" that Gallo should have known that the tests were equivalent. Indeed, he says, even Luc Montagnier, Gallo's French competitor, was emphasizing differences between the viruses at the time. If experience is any guide, resolving this issue could take all year.

\section{Cantekin}

A less well-known case, but one just as relevant to the current controversy over scientific misconduct, is that of Erdem Cantekin, a bioengineer at the University of Pittsburgh.

Last month, the Journal of the American Medical Association published a longdelayed paper by Cantekin accompanied by an unusual fivepage commentary by the West Coast editor, Drum mond Rennie, explaining the paper's

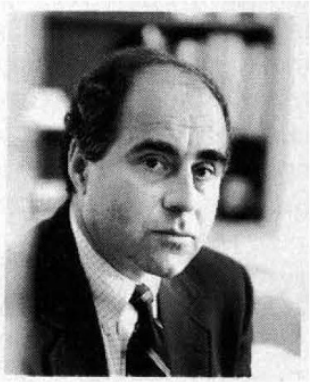

Erdem Cantekin convoluted history. Five years in the making, the story has emerged in bits and pieces. Essentially, Cantekin and Charles Bluestone, another University of Pittsburgh researcher, had collaborated on a clinical trial of an antibiotic known as amoxicillin on ear infections in children. Bluestone concluded that the drug was effective; Cantekin disagreed. In 1986, the two submitted contradictory articles to the New England Journal of Medicine, which asked the university to identify the 'authorized' principal investigator. Pittsburgh identified Bluestone and then began disciplinary action against Cantekin for attempting to take unwarranted credit for the study.

Although an OSI investigation cleared Cantekin of wrongdoing, Pittsburgh has continued its attempts to strip him of tenure. Now that his dissenting paper has finally been published, Cantekin is preparing to take the offensive. He has filed a lawsuit against Bluestone and the hospital where they did the study to attempt to gain possession of the original data, and has served six current and former Pittsburgh officials with a 40-page complaint and intent to sue, charging that they participated in a conspiracy to withhold data from the public and damage his career. He also plans to petition the US Food and Drug Agency to withdraw amoxicillin from use in children's ear infections, something that would effectively halt a market estimated at 30 million prescription a year.

Christopher Anderson

\section{SPACE SCIENCE}

\section{Smaller, cheaper, leaner \\ Washington}

IF funding for the US National Aeronautics and Space Administration (NASA) keeps up with inflation over the next few years, officials will count themselves fortunate. Throughout the agency, planners are rediscovering austerity, and shedding grand space plans as fast as they developed them in the boom years of the late 1980s.

After Congress in 1991 rejected NASA's proposal to start planning for a mission to Mars, the agency is planning to return with a much more modest strategy involving cheap robotic missions. In its 1993 budget request (which will be released next month) NASA is expected to ask for some $\$ 50$ million in start-up funds to begin planning several unmanned missions to the Moon, with the aim of developing techniques that could be used someday on Mars.

The proposed space station, which spent much of 1991 precariously balanced on the edge of cancellation, now seems politically secure, if somewhat battered. Still overweight, underpowered, and needing constant maintenance in its latest planned incarnation, the project has become an mechanical, rather than a political, challenge. "It's up to the engineers to make it work now," says George Washington University space analyst John Logsdon.

But if the space station will not be 1992's whipping boy, the Advanced Solid Rocket Motor may take its place. The \$465-million effort to develop a next generation of engines for the space shuttle owes more to the desire of House Appropriations Committee chairman Jamie Whitten (Democrat, Mississippi) to create jobs in his home state than any pressing NASA needs. Now that the shuttle programme itself has been discontinued, the Administration is planning to put its foot down on what it sees as a particularly egregious example of 'pork barrel' funding. President Bush is expected to seek the cancellation of the project this year, something that seems sure to prompt a nasty response from Whitten and could tangle the rest of the NASA budget in political infighting.

Christopher Anderson 